\title{
Effect of cimetidine and ranitidine on drug induced damage to gastric epithelial cell monolayers in vitro
}

\author{
M ROMANO, M RAZANDI, AND K J IVEY \\ From the Department of Medicine, Long Beach VA Medical Center, and University of California, Irvine, \\ California, USA
}

SUMmARY The effect of the $\mathrm{H}_{2}$ blockers cimetidine and ranitidine on drug induced damage to gastric cell monolayers has been evaluated in conditions independent of systemic factors and their anti-acid properties. Monolayers of mucous cells from a human cell line MKN 28, obtained from a human gastric adenocarcinoma, have been studied. Cell damage has been assessed qualitatively by trypan blue dye exclusion test and quantitatively by ${ }^{51} \mathrm{Cr}$ release assay. Cimetidine and ranitidine significantly protected cultured cells against damage induced by sodium taurocholate decreasing taurocholate induced ${ }^{51} \mathrm{Cr}$ release by $36 \%(\mathrm{p}<0.001)$ and $28 \%(\mathrm{p}<0.01)$, respectively. Cimetidine was also protective in concentrations lower than ranitidine. This protection was not prevented by the prostaglandin synthesis inhibitor indomethacin nor by the sulph-hydryl blocker $\mathbf{N}$-ethylmaleimide. Incubation with cimetidine and ranitidine did not increase the production of $\mathrm{PGE}_{2}$ by cultured cells nor did it affect the cellular level of sulph-hydryl compounds. Cimetidine and ranitidine did not afford protection against damage induced by indomethacin and ethanol. Cimetidine in a concentration of $10^{-4} \mathrm{M}$ increased ethanol induced damage significantly. In conclusion (1) cimetidine and ranitidine protect gastric cells against taurocholate induced damage in vitro, independently of their anti-acid effect; (2) this protection is not mediated by prostaglandin $E_{2}$ or sulph-hydryl compounds; (3) cimetidine and ranitidine do not protect gastric cells against damage induced by indomethacin and ethanol.

Histamine $\mathrm{H}_{2}$ receptor blockers cimetidine and ranitidine have been shown to protect gastric mucosa against aspirin induced damage in vivo 12 Because aspirin induced gastric mucosal damage is dependent on the amount of acid present in the stomach (the more acid, the more damage), $\mathrm{H}_{2}$ blocker protection may be dependent on the inhibition of gastric acid secretion. Cimetidine and ranitidine do not protect rat gastric mucosa in vivo against ethanol induced damage (which is acid independent unlike aspirin) ${ }^{3}$; this further questions the ability of these drugs to protect independently of acid inhibition. On the other hand, $\mathrm{H}_{2}$ antagonists have been reported to be 'cytoprotective' even in non-anti-secretory doses. ${ }^{2+\infty}$

The mechanism of the protection by cimetidine and ranitidine is unknown. Prostaglandins did not

Address for correspondence: Kevin J Ivey, MD, GI Division (IIIG), VA Medical (enter, 5901 E 7th Street. L.ong Beach, CA 90822. USA.

Accepted for publication 9 February 1989. appear to be involved in the protective effect exerted by ranitidine in vivo. ${ }^{2}$ The effect of cimetidine on prostaglandin production by gastric mucosa is controversial. ${ }^{78}$ Sulph-hydryl compounds such as cysteamine protect against drug induced damage in vivo and in vitro. ${ }^{11}$ "Whether endogenous sulphhydryls mediate the protective effect of the $\mathrm{H}_{2}$ blockers has not been determined. Furthermore, whether $\mathrm{H}_{2}$ blockers are able to protect gastric mucosal cells directly, independently of the influence of systemic factors such as blood flow, hormonal, and vascular factors or bicarbonate secretion has not been reported.

The aim of the present study was to evaluate the effect of $\mathrm{H}_{2}$ blockers on taurocholate, indomethacin, and ethanol induced damage to gastric epithelial cells in vitro. Gastric mucosal cell monolayers were derived from a cell line, MKN 28, obtained from a human gastric adenocarcinoma, which has been shown to be suitable for the study of cytoprotection 
by agents such as these in vitro. ${ }^{11}$ In this experimental model, the influence of vascular, neural, and hormonal factors is excluded. Furthermore, as MKN 28 cells are mucus producing cells, the acid inhibitory property of $\mathrm{H}_{2}$ blockers is not relevant to their protective effect. The mechanism of this protection has been investigated by comparing two $\mathrm{H}_{2}$ blockers of differing potency and by evaluating the role of prostaglandins and endogenous sulph-hydryl compounds.

\section{Methods}

MATERIAL

The MKN 28 cell line is derived from a well differentiated human gastric adenocarcinoma consisting of mucus secreting epithelial cells. '2 Culture medium consisted of a 1:1 mixture of Dulbecco's modified Eagle medium (DME) and Coon's modified Ham's F-12 medium (both from GIBCO, Grand Island, NY). Culture medium was supplemented with $15 \mathrm{mM}$ HEPES buffer (Sigma Chemical Co, St Louis, Mo), $1.2 \mathrm{~g} / \mathrm{I} \mathrm{NaHCO}_{3}$ (Sigma), heat inactivated (at $56^{\circ} \mathrm{C}$ for $30 \mathrm{~min}$ ) $10 \%$ fetal bovine serum (Armour Pharmaccutical Co, Kankakee, III), and $1 \%$ antibiotic antimycotic solution $(100 \mathrm{U} / \mathrm{ml}$ penicillin, $100 \mu \mathrm{g} / \mathrm{ml}$ streptomycin, $0.25 \mu \mathrm{g} / \mathrm{ml}$ fungizone) obtained from Irvine Scientific Co, Santa Ana, Cal. Ranitidine was a gift from Glaxo Research Group Ltd. Cimetidine, sodium taurocholate, indomethacin, and N-ethylmaleimide (NEM) were purchased from Sigma. Chromium 51 (sodium chromate $200-900 \mathrm{Ci} / \mathrm{g}$ chromium) and trypsin were from ICN Biomedicals, Irvine, Cal ( $\left.{ }^{125} \mathrm{I}\right)$ prostaglandin $E_{2}$ radioimmunoassay kit was obtained from New England Nuclear, Boston, Mass. Reduced glutathione, 5,5-dithiobis-2-nitrobenzoic acid, and sulphosalicylic acid were purchased from Sigma. Sodium taurocholate, $\mathrm{N}$-ethylmaleimide, and ranitidine were dissolved in DME-F12 medium and used immediately after adjusting $\mathrm{pH}$ to $7 \cdot 4$. A stock solution of indomethacin $50 \mathrm{mM}$ was obtained by dissolving the drug in $\mathrm{Na}_{2} \mathrm{CO}_{3}$ (Sigma) $0 \cdot 2 \mathrm{M}$; $\mathrm{pH}$ was adjusted to 7.4 by adding $\mathrm{NaH}_{2} \mathrm{PO}_{4}$. Desired concentrations of the drug were obtained by diluting the stock solution with culture medium ( $\mathrm{pH} 7 \cdot 4)$. A stock solution of cimetidine $100 \mathrm{mM}$ was prepared by dissolving the drug in dimethyl sulphoxide. The drug solution was aliquoted and stored frozen $\left(-20^{\circ} \mathrm{C}\right)$ until the experiment day. Desired concentrations were obtained by diluting the stock solution with DME-F12 medium.

CELL CULTURE

MKN 28 cells were grown as monolayers in DMEF12 medium and confluent monolayers were sub- cultured every four days by treatment with $0 \cdot 1 \%$ trypsin and $0.03 \%$ EDTA (Sigma) in $\mathrm{CA}^{+-}$- and $\mathrm{Mg}^{+}$-free phosphate buffered saline. After trypsin treatment, cells were plated onto $35 \times 10 \mathrm{~mm}$ culture dishes (Corning, Corning, NY). Cells were studied when they were at the confluent state, usually from four to five day old cultures. The cultures were maintained in a stericult incubator (Forma Scientific, Marietta, Ohio) at $37^{\circ} \mathrm{C}$ in a humidified atmosphere of $5 \% \mathrm{CO}_{2}$ in air. The medium was changed every other day. MKN 28 cells have been previously identified as mucus producing cells histochemically and electron microscopically. ${ }^{112}$

51 CHROMIUM RELEASE ASSAY

The method for isotope release assay was as described previously..$^{131+}$ The media were discarded and the monolayers washed three times with $1 \mathrm{ml}$ medium $\left(37^{\circ} \mathrm{C}\right)$ to remove floating cells in culture. The cells were then incubated in medium containing $5 \mu \mathrm{Ci} / \mathrm{ml}$ of ${ }^{51} \mathrm{Cr}$ for $60 \mathrm{~min}$ in the culture condition. The labelled cells were washed five times with medium $\left(4^{\circ} \mathrm{C}\right)$ to remove excess isotope and then $1 \mathrm{ml}$ medium containing test reagents as described under experimental studies was added to monolayers. After incubation for the experimental period in the culture condition, supernatant medium was collected. The monolayers were dissolved in $1 \mathrm{~N} \mathrm{NaOH}$ for 24 hours. Radioactivity of the cells and of the supernatants was counted with an automatic gamma counter (Beckman 7000, Beckman Instruments Inc, Fullerton, Cal). The percentage of ${ }^{\text {" }} \mathrm{Cr}$ release per sample was expressed as:

${ }^{5}$ Cr Release $(\%)=\frac{\text { cpm supernatant }}{\text { cpm supernatant }+ \text { cpm cells }} \times 100$

or as:

Specific ${ }^{5} \mathrm{Cr}$ Relcase $(\%)={ }^{\circ} \mathrm{Cr}$ release $(\%)$ in the presence of the test drug - spontaneous ${ }^{51} \mathrm{Cr}$ release $(\%)$ - that is, ${ }^{\text {"Cr }} \mathrm{Cr}$ rease in control monolayers. The medium used in ${ }^{5} \mathrm{Cr}$ relcase assay was not supplemented with fetal bovine serum and was antibiotic-antimycotic free.

TRYPAN BLUE DYE EXCLUSION TEST

Trypan bluc dye exclusion test was carricd out as described elsewhere. ${ }^{1516}$ Briefly, after incubation with test drugs, monolayers were washed three times with F-12 medium. Washed monolayers were kept in $1 \mathrm{ml} \mathrm{F}-12$ medium until the test was performed. One tenth of a millilitre of trypan blue $(0 \cdot 4 \%)$ was then added to monolayers and mixed. Ten minutes later, monolayers were observed in an inverted phase 

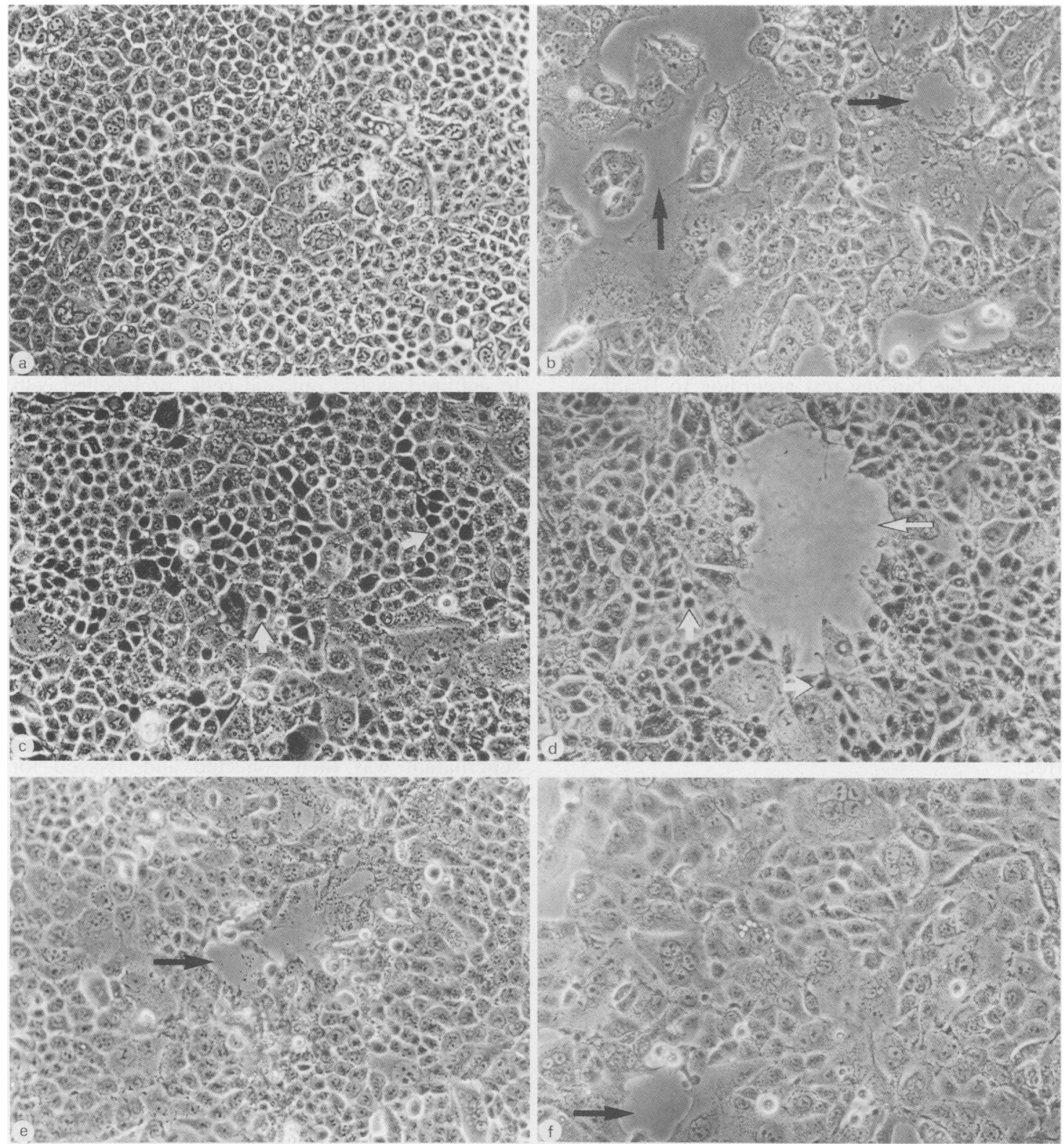

Fig. 1 Phase contrast photomicrograph of four day old cultures of MKN 28 cells. (a) Control monolayer incubated with medium only. (b) Monolayer incubated with sodium taurocholate $10 \mathrm{mM}$ for $30 \mathrm{~min}$. Arrows indicate holes which represent areas formed from cells which died and were detached. (c) Monolayer treated with indomethacin $5 \mathrm{mM}$ for $60 \mathrm{~min}$. Many cells are dead and stained darkly with trypan blue (arrows) (d) Monolayer treated with ethanol $15 \%$ for 30 min showing cell damage. Short arrows indicate cells stained darkly with trypan blue. Long arrow shows a large hole resulting from detached cells. (c) and (f) Monolayers pretreated with cimetidine $10^{\circ} \mathrm{M}$ and ranitidine $10^{\circ} \mathrm{M}$, respectively, before the addition of sodium taurocholate $10 \mathrm{mM}$. The structure of the monolayers is still disorganised but the amount of cell damage is less than in (b) with fewer holes (arrows) caused by detachment of dead cells. 
contrast microscope by an observer unaware of treatment.

RADIOIMMUNOASSAY OF PROSTAGLANDIN E, Monolayers were washed three times with DME-F12 medium $\left(37^{\circ} \mathrm{C}\right)$ and incubated with medium for 30 min for further washing. This medium was discarded and monolayers were incubated with medium containing test reagents or medium only (control) for 60 min. The medium was collected and centrifuged for $5 \mathrm{~min}$ at $2000 \mathrm{rpm}$ and $4^{\circ} \mathrm{C}$. The supernatant was collected and stored at $-70^{\circ} \mathrm{C}$ in $\mathrm{N}_{2}$ atmosphere until assayed. The pellets were combined with corresponding monolayers and protein was determined with the dye binding test according to Bradford. ${ }^{17}$ $\mathrm{PGE}_{2}$ was measured directly in duplicate with a highly sensitive ${ }^{125} 1$ radioimmunoassay kit. Standards in the range of 0.2 to $50 \mathrm{pg} \mathrm{PGE}_{2}$ were treated in the same way as the samples and the curve calculated on semilogarithmic paper after counting in a Beckman 7000 gamma counter. The limit of detection was $0.1 \mathrm{pg} \mathrm{PGE}_{2}$ in $0.1 \mathrm{ml}$ volume per assay tube. For $\mathrm{PGE}_{2}$, cross reactivity with prostaglandin $E_{1}$ was $3.7 \%$ and with all other prostaglandins less than $0 \cdot 4 \%$. Cross reactivity between drugs and antisera to $\mathrm{PGE}_{2}$ was evaluated in each assay experiment and found to be not significant. The medium used in $\mathrm{PGE}_{2}$ radioimmunoassay was not supplemented with fetal bovine serum and was antibiotic antimycotic free.

DETERMINATION OF TOTAL REDUCED SOI.UBI.E S ULPH-HYDRYLS

Reduced soluble sulph-hydryl content was measured as follows. ${ }^{1819}$ After incubation for the experimental periods, monolayers were washed three times with $0.02 \%$ EDTA in phosphate buffered saline (PBS); then, $1.4 \mathrm{ml} 0 \cdot 2 \%$ Triton $\mathrm{X}-100$ and $2.5 \%$ sulphosalicylic acid in EDTA/PBS buffer was added to monolayers. Cells were scraped off with a rubber policeman and sonicated. Solutions were cleared by centrifugation at $11000 \mathrm{~g}$ for five minutes. A $1 \mathrm{ml}$ aliquot of the acid soluble supernatant medium was then added to $2.0 \mathrm{ml} 0.3 \mathrm{M} \mathrm{Na} \mathrm{HPO}_{4}$ buffer. Spectrophotometric determinations were performed with a Gilford Stasar II spectrophotometer (Gilford Instruments Laboratories Inc, Oberlin, Ohio) at 412 $\mathrm{nm}$ immediately after the addition of $0.25 \mathrm{ml}$ of $5,5-$ dithiobis-2-nitrobenzoic acid $(40 \mathrm{mg} / \mathrm{dl}$ in $1 \%$ sodium citrate)." With each assay a standard curve was generated with known amounts of reduced glutathione $(10-100 \mathrm{nmol} / \mathrm{ml})$. Results are expressed as nanomoles of soluble reduced sulph-hydryls $/ 10^{\circ}$ cells. The medium used in sulph-hydryl assay experiments was not supplemented with fetal bovine serum and was antibiotic antimycotic frec.

\section{Experimental studies}

DRUG INDUCED DAMAGE TO CULTUREDGASTRIC MUCOSAI. CELLS

Prelabelled cells were incubated with medium containing sodium taurocholate $5-15 \mathrm{mM}$, or indomethacin $2.5-10 \mathrm{mM}$, or ethanol 5-20\%, or medium only, control. Incubation was $30 \mathrm{~min}$ with sodium taurocholate or ethanol and $60 \mathrm{~min}$ with indomethacin.

EFFECT OF CIMETIDINE AND RANITIDINE ON VIABIIITY OF CULTURED CEILLS AND ON DRUG; INDUCED DAMAGE

To assess whether $\mathrm{H}_{2}$ blockers produce any damage to cultured gastric mucosal cells, prelabelled cells were incubated with cimetidine or ranitidine 10 " to $10^{4} \mathrm{M}$ or medium only (control), for $60 \mathrm{~min}$. In order to evaluate whether cimetidine and ranitidine protect gastric cells against drug induced damage, prelabelled cells were preincubated with cimetidine or ranitidine $10^{-x}$ to $10^{+4} \mathrm{M}$ or medium only (control) for $60 \mathrm{~min}$ and then with sodium taurocholate $10 \mathrm{mM}$ (30) $\mathrm{min})$, or indomethacin $5 \mathrm{mM}(60 \mathrm{~min})$, or ethanol $15 \%(30 \mathrm{~min})$.

EFFECT OF INDOMETHACIN ON PGE2

PRODUCTION BY CULTURED CELLS

Cells were incubated with indomethacin $10^{*}$ to $10^{-4} \mathrm{M}$ or medium only (control) for $60 \mathrm{~min}$. Cell free supernatant was then collected and assayed for $\mathrm{PGE}_{2}$.

EFFECT OF INDOMETHACIN ON CIMETIDINE AND RANITIDINE INDUCED PROTECTION

After preincubation with indomethacin $10^{+} \mathrm{M}$ or medium only (control) for $60 \mathrm{~min}$, prelabelled cells were incubated with cimetidine or ranitidine $10{ }^{\circ} \mathrm{M}$ for $60 \mathrm{~min}$ and then with sodium taurocholate $10 \mathrm{mM}$ for $30 \mathrm{~min}$.

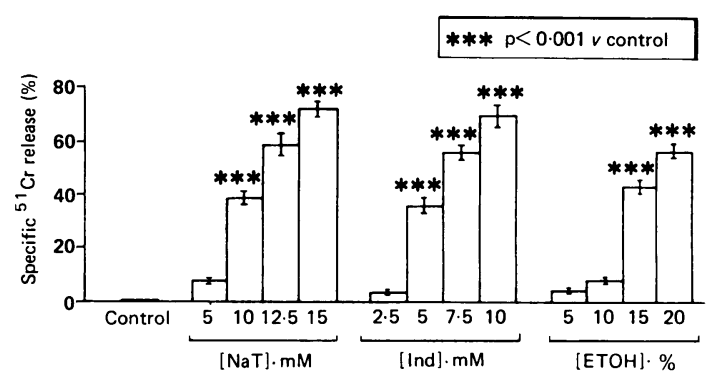

Fig. 2 Sodium taurocholate ( $\mathrm{NaT}$ ), indomethacin (Ind), and ethanol (ETOH) damage' cultured cells in a dose' dependent manner, as assessed quantitatively by "(r release assay. Mean (SE) of seven cultures (taurocholate) and six cultures (indomethacin and ethanol). 
EFFECT OF N-ETHYIMAIIEIMIDE ON TOTAI.

REDU(ED SOI.UBI.E SUI.PH-HYIDRYI.

Cells were incubated with N-ethylmaleimide (0.01$0.5 \mathrm{mM}$ or medium only (control) for $30 \mathrm{~min}$. Cells were then harvested and sulph-hydryl content measured.

EFFE(T OF N-ETHYIMAI.EIMIDE ON CIMETIDINE AND RANITIDINEINDUCED PROTECTION

After $30 \mathrm{~min}$ incubation with ranitidine $10^{\circ} \mathrm{M}$, the sulph-hydryl blocker agent $\mathrm{N}$-ethylmaleimide was added at a final concentration of $0.05 \mathrm{mM}$. After 30 $\mathrm{min}$, monolayers were washed and incubated with sodium taurocholate $10 \mathrm{mM}$ for $30 \mathrm{~min}$.

EFFECT OF CIMETIDINE AND RANITIDINE ON PGE $_{2} \wedge$ ND SULPH-HYDRYL. PRODUCTION BY CULTURED CELLS

Monolayers were incubated with cimetidine or ranitidine $10{ }^{7}$ to $10{ }^{4} \mathrm{M}$ or medium only (control) for $60 \mathrm{~min}$. Cell free supernatant was then collected and assayed for $\mathrm{PGE}_{2}$. Cells were harvested and sulphhydryl content measured colorimetrically.

STATISTICAL. ANALYSIS

Data are expressed as mean standard error of mean (SE). Significance of differences was assessed by oneway analysis of variance and, when the $F$ value was significant, by Duncan's new Multiple Range Test." Differences were considered significant if $p<0 \cdot 05$. Dose dependency was assessed by regression analysis.

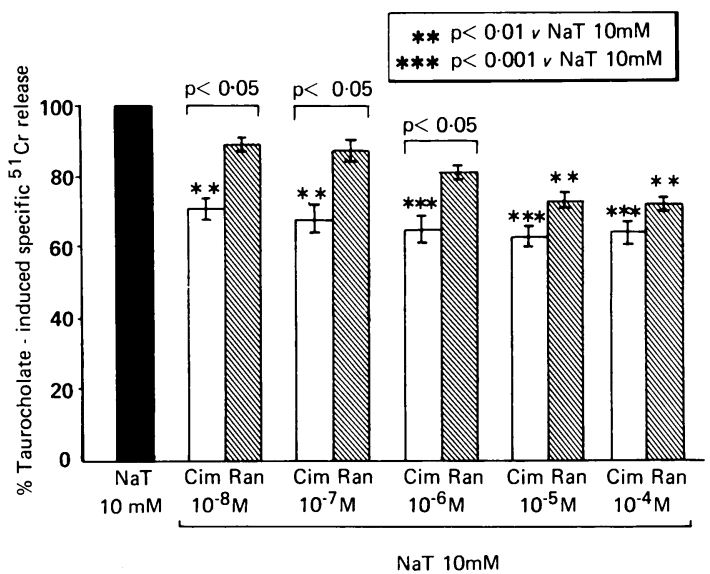

Fig. 3 Cimetidine (Cim), at all dose levels $10^{\times}$to $10^{+} \mathrm{M}$ and ranitidine (Ran) at dose levels $10^{5}$ and $10^{\circ}$ only, significantly reduced $10 \mathrm{mM}$ sodium taurocholate $(\mathrm{NaT})$ induced damage to cultured gastric mucosal cells. Cimetidine and ranitidine $10^{5} \mathrm{M}$ decreased taurocholate-induced specific "Cr release by $37 \%$ and $27 \%$, respectively. Mean $(S E)$ of nine cultures.
The data for ${ }^{5} \mathrm{Cr}$ release related to the effect of $\mathrm{H}_{2}$ blockers on taurocholate induced damage have been analysed before normalisation versus taurocholate induced specific ${ }^{51} \mathrm{Cr}$ release.

\section{Results}

CELI. CULTURE AND DRUG INDUCED MORPHOLOGICAL CHANGES

Figure la shows a four day old culture of MKN 28 cells. These cells have been shown to be mucus producing cells by means of histochemical staining (PAS positive, negative reaction for succinic dehydrogenase and for pepsinogen granules) and electron microscopy." "' Figures $1 \mathrm{~b}$ to $1 \mathrm{~d}$ shows that incubation with sodium taurocholate $10 \mathrm{mM}$ (Fig. 1b), indomethacin $5 \mathrm{mM}$ (Fig. 1c), or ethanol 15\% (Fig. 1d), respectively, disrupted the structure of the monolayer causing death of a large percentage of cells. Pretreatment with cimetidine (Fig. 1e) and ranitidine (Fig. 1f), reduced the damage induced by sodium taurocholate but not by indomethacin or ethanol.

EFFECT OF TAUROCHOLATE, INDOMETHACIN, AND ETHANOL ON VIABILITY OF CULTURED CELLS

Sodium taurocholate, indomethacin, and ethanol damaged monolayers in a dose dependent manner as assessed quantitatively by ${ }^{~} \mathrm{Cr}$ release assay $(\mathrm{r}=0.97$, $\mathrm{p}<0.01$ with taurocholate, $\mathrm{r}=0.97, \mathrm{p}<0.01$ with indomethacin, $r=0.90, p<0.05$ with ethanol) (Fig. 2).

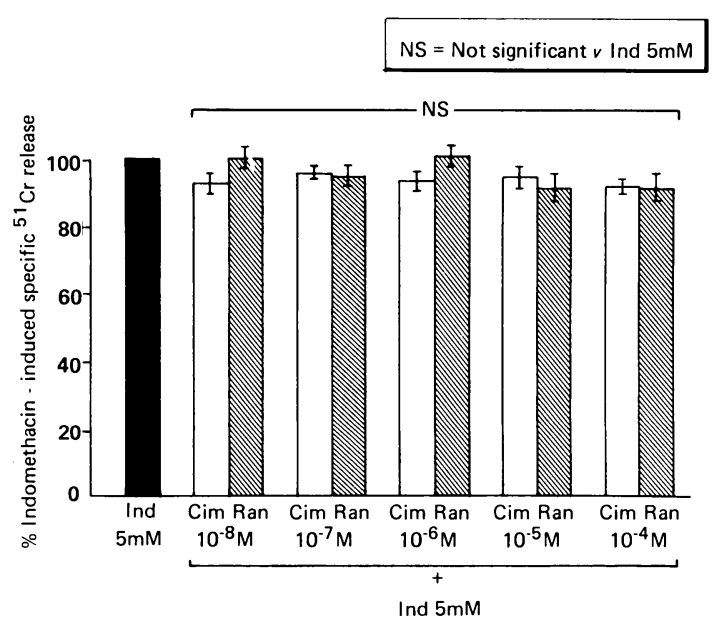

Fig. 4 Cimetidine (Cim) and ranitidine (Ran) did not prevent cell damage induced by indomethacin $5 \mathrm{mM}$ (Ind). Mean (SE) of nine cultures. 


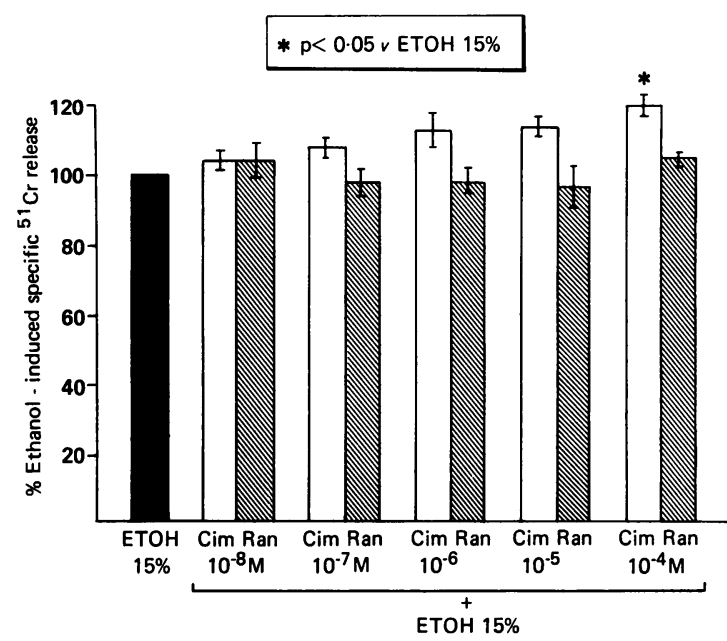

Fig. 5 Cimetidine (Cim) and ranitidine (Ran) did not exert a protective effect against $15 \%$ ethanol $(E T O H)$ induced damage. Cimetidine, but not ranitidine, showed a tendency to increase ethanol induced specific ${ }^{51} \mathrm{Cr}$ release; this was significant at the concentration of $10^{+} \mathrm{M}$. Mean (SE) of nine cultures.

\section{EFFECT OF CIMETIDINE AND RANITIDINE ON} DRUG INDUCED DAMAGE

Cimetidine and ranitidine over the range of concentrations used did not produce any significant change in ${ }^{51} \mathrm{Cr}$ release by cultured cells as compared with control. Cimetidine $10^{-8}$ to $10^{-4} \mathrm{M}$ decreased significantly the ${ }^{51} \mathrm{Cr}$ release induced by sodium taurocholate $10 \mathrm{mM}$. Cimetidine $10^{-5} \mathrm{M}$ decreased taurocholate induced specific ${ }^{51} \mathrm{Cr}$ release by $37 \%(\mathrm{p}<0.001)$ (Fig. 3). Ranitidine $10^{-5} \mathrm{M}$ and $10^{-4} \mathrm{M}$ caused significant protection $(\mathrm{p}<0 \cdot 01)$ decreasing taurocholate induced damage by $27 \%$. Ranitidine did not afford significant protection in the lower concentrations $10^{-8}$ to $10^{-6} \mathrm{M}$ (Fig. 3). Cimetidine and ranitidine did not reduce indomethacin and ethanol induced damage (Figs 4 and 5, respectively). Cimetidine, but not ranitidine, showed a tendency to increase ethanol induced specific ${ }^{51} \mathrm{Cr}$ release; this was significant at the concentration of $10^{-4} \mathrm{M}$ (Fig. 5).

EFFECT OF INDOMETHACIN AND N-

ETHYLMALEIMIDE ON CIMETIDINE AND

RANITIDINE INDUCED PROTECTION

Indomethacin $10^{-8}$ to $10^{-4} \mathrm{M}$ decreased $\mathrm{PGE}_{2}$ production by cultured cells in a dose dependent manner (Fig. 6). The concentration of indomethacin $10^{-4} \mathrm{M}$ reduced $\mathrm{PGE}_{2}$ production by cultured cells by $60 \%$ (Fig. 6). Pretreatment with the prostaglandin synthesis inhibitor indomethacin in the concentration of $10^{-4} \mathrm{M}$ did not prevent the protection afforded by cimetidine and ranitidine (Fig. 7).

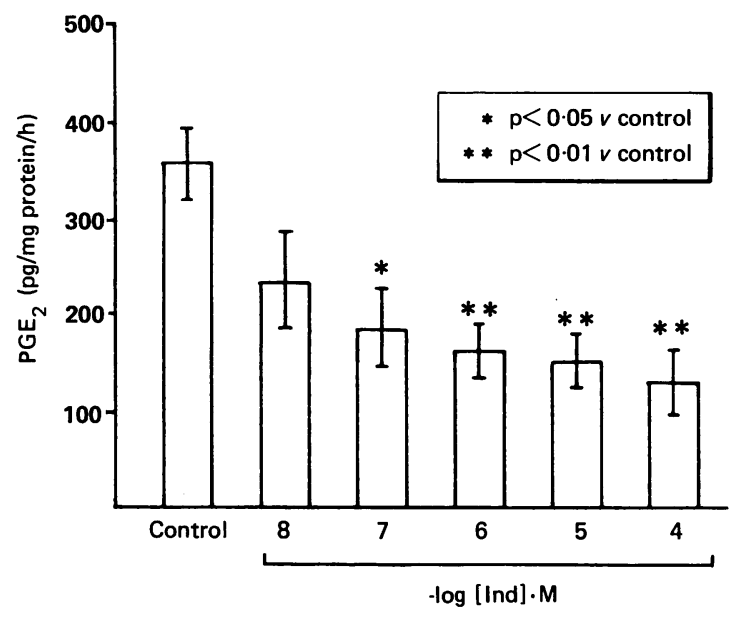

Fig. 6 Indomethacin (Ind) decreased $P G E_{2}$ production by cultured cells in a dose dependent manner. Indomethacin $10^{+} \mathrm{M}$ inhibited $P G E_{2}$ synthesis by approximately $60 \%$. Mean (SE) of five cultures.

$\mathrm{N}$-ethylmaleimide in a concentration of $0.05 \mathrm{mM}$ reduced the sulph-hydryl content of cultured cells by $45 \%$ (Fig. 8). Higher concentrations of N-ethylmaleimide $(0.1$ and $0.5 \mathrm{mM})$ reduced the sulphhydryl content of cultured cells to a much greater extent but these concentrations themselves signifi-

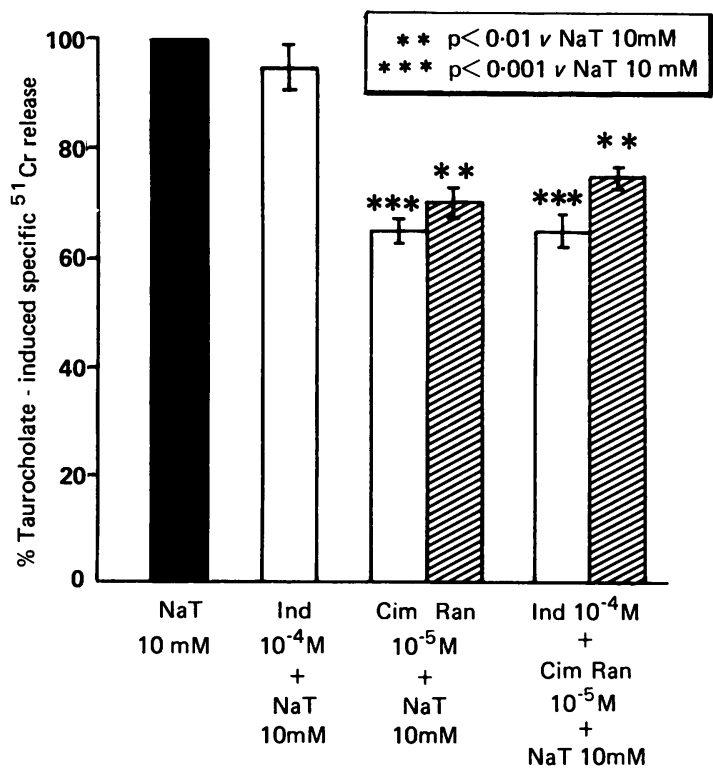

Fig. 7 Prostaglandin synthesis inhibitor indomethacin (Ind) did not prevent the protective effect exerted by cimetidine (Cim) and ranitidine (Ran) against taurocholate $(\mathrm{NaT})$ induced damage. Mean (SE) of eight cultures. 


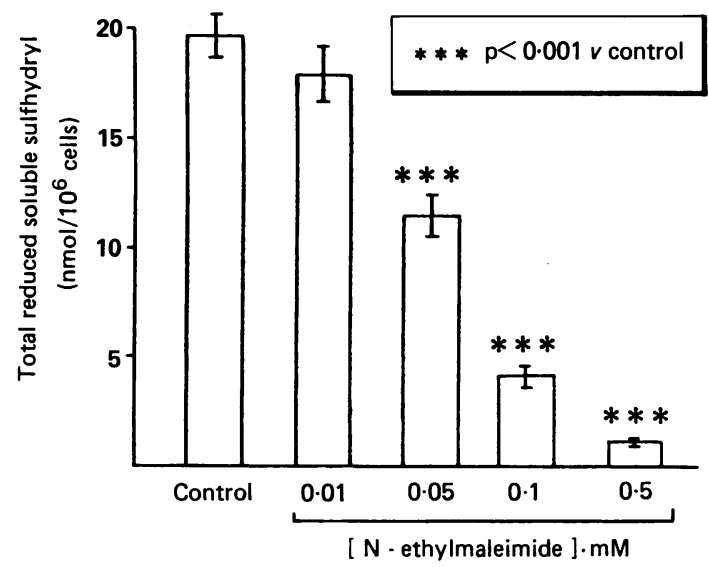

Fig. $8 \quad N$-ethylmaleimide (NEM) significantly and in a dose dependent manner decreased levels of total reduced soluble sulph-hydryls. Mean (SE) of eight cultures.

cantly damaged cells and increased taurocholate induced damage. The sulph-hydryl blocker agent $\mathrm{N}$-ethylmaleimide did not prevent the protection afforded by cimetidine and ranitidine against damage brought about by sodium taurocholate (Fig. 9). Indomethacin and $\mathrm{N}$-ethylmaleimide at the concentrations used did not cause any cell damage nor did they increase taurocholate induced damage (Figs 7 and 9).

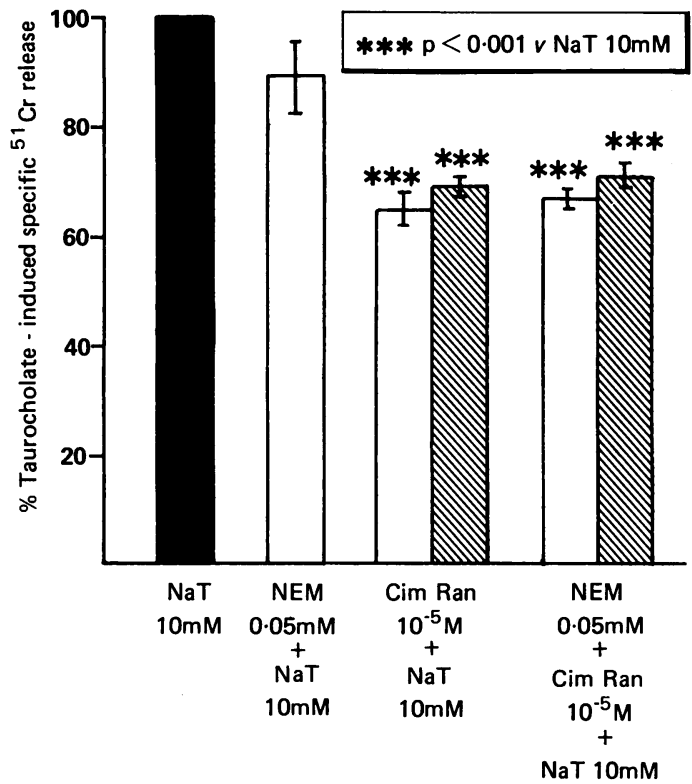

Fig. 9 Sulph-hydryl blocker agent $N$-ethylmaleimide (NEM) did not prevent the protective effect of cimetidine (Cim) and ranitidine (Ran) against taurocholate ( $\mathrm{NaT})$ induced damage. Mean (SE) of six cultures.

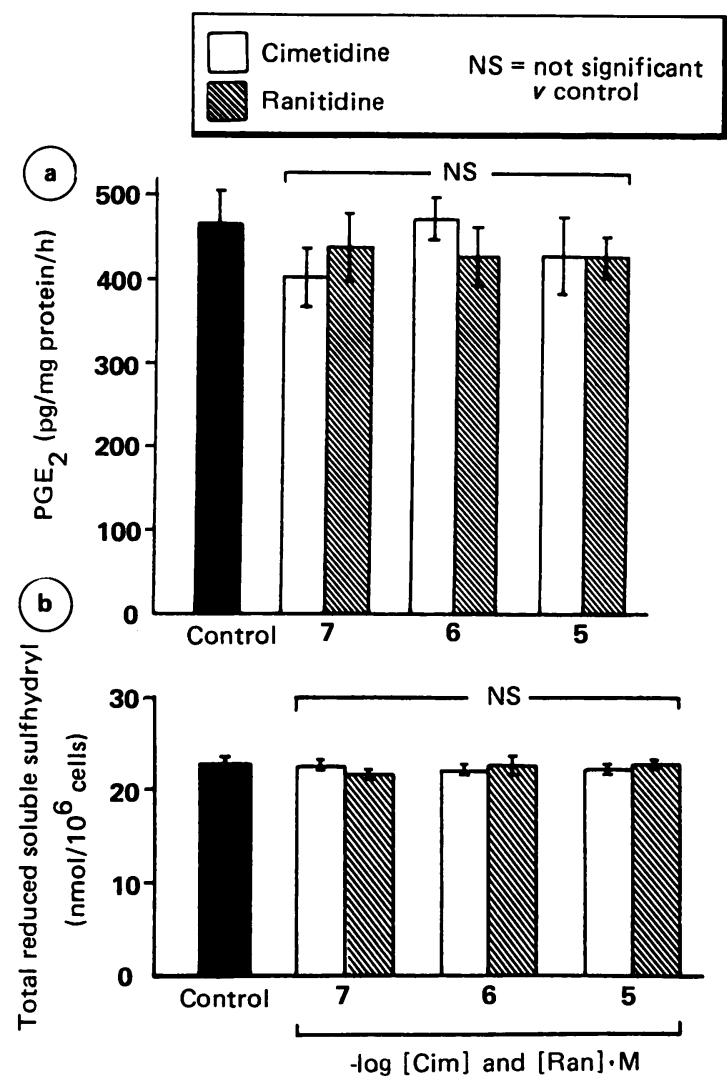

Fig. 10 Cimetidine (Cim) and ranitidine (Ran) did not increase $P G E_{2}$ production by cultured cells (A) nor did they affect total reduced soluble sulph-hydryl content of cells (B). Mean (SE) of six cultures.

EFFECT OF CIMETIDINE AND RANITIDINE ON PGE $_{2}$ AND SULPH-HYDRYL PRODUCTION BY CULTURED CELLS

MKN 28 cells produced $\mathrm{PGE}_{2}$ in the amount of 458 (37) $\mathrm{pg} / \mathrm{mg}$ protein $/ \mathrm{h}$. Incubation with cimetidine and ranitidine did not increase $\mathrm{PGE}_{2}$ production by cultured cells (Fig. 10). The cellular content of reduced sulph-hydryl compounds was 22.7 (1) $\mathrm{nmol} / 10^{\text {h }}$ cells. Cimetidine and ranitidine did not affect the sulph-hydryl content of monolayers (Fig. $10)$.

\section{Discussion}

This study shows that the histamine $\mathrm{H}_{2}$ receptor blocking agents cimetidine and ranitidine are able to protect gastric mucosal cells grown in tissue culture against drug induced damage in conditions independent of their acid inhibitory effect as well as of systemic factors. This protection occurs against 
sodium taurocholate, but not against indomethacin or ethanol induced damage. Endogenous prostaglandin and sulph-hydryl compounds do not appear to play a major role in the protective effect exerted by cimetidine and ranitidine.

The $\mathrm{H}_{2}$ blockers cimetidine and ranitidine have been shown to protect against gastric mucosal damage induced by aspirin in vivo. ${ }^{1223}$ Cimetidine and ranitidine do not, however, protect rat gastric mucosa against ethanol induced damage in vivo. ${ }^{32+5}$ As aspirin induced gastric mucosal damage is dependent on the $\mathrm{pH}$ of gastric content, ${ }^{26}$ whereas ethanol induced damage is not, ${ }^{77} 2 \mathrm{H} \mathrm{H}_{2}$ blocker mediated protection of gastric mucosa in vivo may merely be the result of inhibition of gastric acid secretion and, therefore, not true cytoprotection. On the other side, $\mathrm{H}_{2}$ antagonists have been shown to be protective in non-anti-secretory doses. ${ }^{\text {th }}$ Also, Hogan et al have recently shown that cimetidine decreases the damaging effect of acute aspirin administration on the human gastric mucosa in conditions independent of suppression of gastric acid secretion."- Using an experimental model of mucus producing cells and carrying out experiments at $\mathrm{pH} \mathrm{7.4}$ we found cimetidine and ranitidine significantly protected gastric cells against taurocholate induced damage. These findings are in agreement with a report from Utley et al who found protection by cimetidine against taurocholate induced damage to rat gastric mucosa. ${ }^{29}$ Also, Muller et al reported that ranitidine prevents the taurocholate induced drop in gastric mucosal potential difference in man. ${ }^{311}$ Cimetidine and ranitidine $10^{-5} \mathrm{M}$ decreased taurocholate induced ${ }^{51} \mathrm{Cr}$ release by $37 \%(p<0.001)$ and $28 \%(p<0.01)$, respectively. Cimetidine exerted a significant protective effect also in lower concentrations $\left(10^{-8}\right.$ to $\left.10^{-6} \mathrm{M}\right)$, whereas ranitidine protected cells only in higher concentrations $\left(10^{-5}\right.$ and $\left.10^{+} \mathrm{M}\right)$. Both cimetidine and ranitidine failed to prevent the damaging effect of indomethacin and ethanol. This is in agreement with other in vitro studies which showed no protection by cimetidine against damage induced by indomethacin to rat gastric mucosal cells or isolated rat gastric glands. ${ }^{3132}$ Tarnawski et al have reported that cimetidine and ranitidine increase the amount of damage induced by ethanol to rat gastric mucosa in vivo. ${ }^{3}$ Our findings are in partial agreement with this study in as much as we found a significant increase in ethanol induced cell damage after pretreatment with cimetidine $10^{-4} \mathrm{M}$, but not with ranitidine. It can be postulated that the cimetidine induced increase in cell damage brought about by ethanol is caused by an inhibitory effect exerted by cimetidine on gastric alcohol dehydrogenase, the enzymatic system responsible for the oxidation of alcohol. ${ }^{33}$

No agents to date in vitro are able to offer complete
$100 \%$ protection against damaging drugs. Prostaglandins, considered to be the ultimate cytoprotective agent, in in vitro tissue culture studies reduced taurocholate induced damage by $30 \%$. ' Failure by $\mathrm{H}_{2}$ blockers and prostaglandins to protect gastric mucosal cells in vitro completely is consistent with the significant percentage of mucosal cell damage in vivo after damaging agents such as ethanol in spite of prostaglandin administration when the tissues are examined microscopically as in the current study. ${ }^{3 .+17}$

The mechanism of the protective effect exerted by cimetidine and ranitidine is unknown. In particular, there is controversy as to the role of endogenous prostaglandin for this protection to occur. The present study shows that pretreatment with the prostaglandin synthesis inhibitor indomethacin does not prevent the protective effect of cimetidine and ranitidine. Furthermore, incubation with cimetidine and ranitidine does not increase the amount of $\mathrm{PGE}_{2}$ produced by cultured cells. These findings are in agreement with those of Hiraishi et al who found no effect of cimetidine on $\mathrm{PGE}_{2}$ and 6-keto $\mathrm{PGF}_{1:}$ production by rat gastric mucosal cells in tissue culture $^{31}$ and with those of Konturek et al who showed that ranitidine, in a cytoprotective concentration, does not prevent aspirin induced inhibition of $\mathrm{PGE}_{2}$ and prostacyclin production by rat gastric mucosa. Because indomethacin does not inhibit prostaglandin production by $100 \%$, a role for prostaglandins in this protection cannot be excluded completely.

Sulph-hydryl containing drugs protect gastric mucosa against exogenous injury." We have recently shown that the sulph-hydryl agent cysteamine protects gastric mucosal cells in tissue culture against taurocholate and indomethacin induced damage ${ }^{\prime \prime \prime}$ and that endogenous sulph-hydryls might be involved in the protection of gastric cells by acetaminophen in vitro. ${ }^{3 \times}$ We have therefore evaluated whether the protective effect of cimetidine and ranitidine was related to endogenous sulph-hydryls. The sulphhydryl blocker $\mathrm{N}$-ethylmalcimide was not able to prevent the protection afforded by cimetidine and ranitidine against taurocholate induced damage nor did incubation with cimetidine and ranitidine affect the cellular level of endogenous sulph-hydryls. Therefore, it seems unlikely that endogenous sulphhydryl compound is involved in the protection exerted by $\mathrm{H}_{2}$ blockers.

Because these experiments have been carried out in vitro in conditions independent of vascular, hormonal, and neural factors, protection against taurocholate induced cell damage must include the direct effect of the $\mathrm{H}_{2}$ blockers on cell membrane or metabolism. Ranitidine and cimetidine affect the barrier function of the external membrane as indicated by preventing trypan blue from penetrating the 
cell and preventing ${ }^{5} \mathrm{Cr}$ efflux; this suggests that the cell membrane is the site of the protective action of the $\mathrm{H}_{2}$ blockers. This is consistent with the physiological properties of taurocholic acid which has a pKa of $1 \cdot 4$. Therefore, at $\mathrm{pH} 7 \cdot 4$ it is entirely in the dissociated state with no lipid solubility or ability to penetrate cell membranes. On the other hand, ethanol and indomethacin are both more capable of penetrating the cell at neutral $\mathrm{pH}$. In a recent study, ${ }^{39}$ Tarnawski et al presented ultrastructural evidence that indomethacin and ethanol produce cell injury by damaging cytoskeletal elements (actin filaments, intermediate filaments, and microtubules) within isolated gastric epithelial cells in vitro. The inability of $\mathrm{H}_{2}$ blockers to protect against damage induced by these agents suggests that while they can protect against the external detergent action of taurocholate to the cell membrane, they are unable to protect against internal cell damage by indomethacin and ethanol. Prostaglandins, on the other hand, do have this protective ability in vitro, in tissue culture ${ }^{15}$ and isolated gland preparations. ${ }^{34}$ The protective effect of the $\mathrm{H}_{2}$ blockers does not seem to be directly mediated by $\mathrm{H}_{2}$ receptors on the cell membrane; ranitidine is a more potent $\mathrm{H}_{2}$ receptor blocker yet it is a less potent protector of the mucosal cell than cimetidine.

In conclusion, (1) cimetidine and ranitidine protected gastric mucosal cells against taurocholate induced damage in conditions independent of their acid inhibitory effect and of systemic factors; (2) cimetidine was effective in lower concentrations than ranitidine, suggesting that protection was not directly related to ability to block $\mathrm{H}_{2}$ receptors on the cell membrane; (3) cimetidine and ranitidine did not protect against indomethacin and ethanol induced damage; (4) cimetidine and ranitidine did not stimulate production of endogenous $\mathrm{PGE}_{2}$ or sulphhydryl compounds; thus the protective effects of cimetidine and ranitidine against taurocholate induced damage seem unlikely to be the result of prostaglandin or sulph-hydryl compounds but (5) are probably because of a direct action at the level of the external cell membrane.

Dr Romano is a visiting scientist from the Istituto di Medicina Generale e Metodologia Clinica, Prima Facolta' di Medicina, Universita' di Napoli, Italy.

\section{References}

I Guth PH, Aures D, Paulson G. Topical aspirin plus HCI gastric lesions in the rat: cytoprotective effect of prostaglandin, cimetidine, and probanthine. Gastroenterology 1979; 76: 88-93.

2 Konturek SJ, Radecki T, Brzozowski T, Piastucki I, Dembinska-Kicc A, Zmuda A. Gastric cytoprotection by prostaglandins, ranitidine, and probanthine in rats. Scand J Gastroenterol 1981; 16: 7-12.

3 Tarnawski A, Hollander D. Gergely H. Stachura J. Comparison of antacid, sucralfate, cimetidine, and ranitidine in protection of the gastric mucosa against cthanol injury. Am J Med 1985; 79 [suppl 2C]: 19-23.

4 Bunce KT, Daly MJ, Humphray JM, Stables R. $\mathrm{H}_{2^{-}}$ receptor antagonists protect against aspirin-induced gastric lesions in the rat. Agents Actions 1981; 11: 16770 .

5 Guth PH, Aures D, Paulsen G. Topical aspirin plus $\mathrm{HCl}$ gastric lesions in the rat. Gastroenterology 1979; 76: 8893.

6 Kauffman GL, Grossman MI. Prostaglandin and cimetidine inhibit the formation of ulcers produced by parenteral salicylates. Gastroenterology 1978; 75: 1099102.

7 Branski D, Sharon P, Karmeli F, Rachmilewitz D. Effect of cimetidine on human gastric and duodenal prostanoid synthesis. Scand J Gastroenterol 1984; 19: $457-60$.

8 Kobayashi K, Nakamura H, Arakawa T. Cimetidine inhibits prostaglandin biosynthesis in rat gastric mucosa in vivo and in vitro [Abstract]. Gastroenterology 1985; 88: 1450 .

9 Szabo S, Trier JS, Frankel PW. Sulfhydryl compounds may mediate gastric cytoprotection. Science 1981; 214: 200-2.

10 Romano M, Razandi M, Raza A, Szabo S, Ivey KJ. Protection of human gastric epithelial cells in vitro by the sulfhydryl agent cysteamine is not related to stimulation of prostaglandin synthesis [Abstract]. Gastroenterology 1987; 92: 1600.

11 Romano M, Razandi M, Sekhon S, Krause WJ, Ivey KJ. Human cell line for study of damage to gastric epithelial cells in vitro. $J$ Lab Clin Med 1988; 111: 430-40.

12 Hojo H. Establishment of cultured cell lines of human stomach cancer. Origin and their morphological characteristics. Niigata Igakukai Zassi 1977; 91: 737-63.

13 Wigzell $\mathrm{H}$. Quantitative titrations of mouse $\mathrm{H}-2$ antibodies using ${ }^{5} \mathrm{Cr}$ labelled target cells. Transplantation 1975; 3: 423-31.

14 Terano A, Mach T, Stachura J, Tarnawski A, Ivey KJ. Effect of 16.16 dymethyl prostaglandin $E_{2}$ on aspirin induced damage to rat gastric epithelial cells in tissue culture. Gut 1984; 25: 19-25.

15 Terano A, Ota S, Mach T, et al. Prostaglandin protects against taurocholate-induced damage to rat gastric mucosal cell culture. Gastroenterology 1987; 92: 669-77.

16 Phillips HJ. Dye exclusion tests for cell viability. In: Krause PF, Patterson MK, eds. Tissue culture methods and application. New York: Academic Press, 1973: 406-8.

17 Bradford MM. A rapid and sensitive method for the quantitation of microgram quantities of protein utilizing the principle of protein-dye binding. Anal Biochem 1976; 72: 248-54.

18 Harlan JM, Levine JD, Callahan KS, Schwartz BR, Harker LA. Glutathione redox cycle protects cultured endothelial cell against lysis by extracellularly generated hydrogen peroxide. J Clin Invest 1984; 73: 706-13.

19 Hiraishi H, Terano A, Ota S. Ivey KJ, Sugimoto T. 
Oxygen reactive metabolite-induced cytotoxicity to cultured rat gastric mucosal cells. Am J Physiol 1987; 253: G40-8.

20 Beutler E, Duron O. Kelly BM. Improved method for the determination of blood glutathione. J Lab Clin Med 1963; 61: 882-8.

21 Duncan DB. Multiple range and multiple $F$ tests. Biometrics 1955; 11: 1-42.

22 Hogan DL. Thomas FJ, Isenberg JI. Cimetidine decreases aspirin-induced gastric mucosal damage in humans. Aliment Pharmacol Ther 1987; 1: 383-90.

23 Berkowitz JM, Adler SN, Sharp JT, Warner CW. Reduction of aspirin-induced gastroduodenal damage with ranitidine. J Clin Gastroenterol 1986; 8: 377-80.

24 Del Soldato P. Foschi D, Varin L, Daniotti S. Comparison of the gastric cytoprotective properties of atropine, ranitidine and $\mathrm{PGE}_{2}$ in rats. Eur J Pharmacol 1985; 106: 53-58.

25 Bright-Asare P, Yamini S, Enrique C, Brown J. Cimetidine and ranitidine do not prevent duodenal ulcers induced by 24 hours infusion of (acidified) ethanol in $(0 \cdot 1$ $\mathrm{N} \mathrm{HCl}$ [Abstract]. Gastroenterology 1986; 90: 1358.

26 Cooke AR. The role of acid in the pathogenesis of aspirin-induced gastrointestinal erosions and hemorrhage. Am J Dig Dis 1973; 18: 225-37.

27 Davenport HW. Ethanol damage to canine oxyntic glandular mucosa. Proc Soc Exp Biol Med 1967; 126: $657-662$.

28 Robert A, Nezamis JE, Lancaster C. Hanchar AJ. Cytoprotection by prostaglandins in rats. Prevention of gastric necrosis produced by alcohol, $\mathrm{HCl}, \mathrm{NaOH}$, hypertonic $\mathrm{NaCl}$, and thermal injury. Gastroenterology 1979; 77: 433-43.

29 Utley RJ, Salim ASM, Carter DC. Effect of cimetidine and omeprazole on aspirin- and taurocholate-induced gastric mucosal damage in the rat. Gut 1985; 26: $770-5$.

30 Muller P, Kather H, Simon B, Damman HG. Prevention of taurocholate-induced drop in gastric potential difference with ranitidine in man. Dig Dis Sci 1982; 27: $765-6$.
31 Hiraishi H, Terano A. Ota S, Ivey KJ, Sugimoto T. Effect of cimetidine on indomethacin-induced damage in cultured rat gastric mucosal cells; comparison with prostaglandin. J Lab Clin Med 1986; 108: 608-15.

32 Brzozowski T, Tarnawski A, Hollander D, Sekhon S, Krause WJ, Gergely H. Comparison of prostaglandin and cimetidine in protection of isolated gastric glands against indomethacin injury. Histologic. ultrastructural, and functional assessment [Abstract]. Gastroenterology 1986; 90: 1360).

33 Caballeria J, Baraona E, Lieber CS. Cimetidine inhibits gastric alcohol dehydrogenase $(\mathrm{ADH})$ and increases blood levels of ethanol after drinking [Abstract]. Gastroenterology 1987: 92: 1722.

34 Guth P, Paulsen G, Nagata H. Histologic and microcirculatory changes in alcohol-induced gastric lesions in the rat. Effect of prostaglandin cytoprotection. Gastroenterology 1984; 87: 1083-90.

35 Schmidt KL, Henagen JM, Smith GS, Hilburn PH, Miller TA. Prostaglandin cytoprotection against ethanol-induced gastric injury in the rat. A histologic and cytologic study. Gastroenterology 1982: 88: 649-59.

36 Tarnawski A, Hollander D, Stachura J, Krause WJ, Gergely $H$. Prostaglandin protection of the gastric mucosa against alcohol injury - a dynamic time-related process. Role of the mucosal proliferative zone. Gastroenterology 1985; 88: 334-52.

37 Whittle BJ, Stecl G. Evaluation of the protection of rat gastric mucosa by a prostaglandin analogue using cellular enzyme marker and histologic techniques. Gastroenterology 1985; 88: 315-27.

38 Romano M, Razandi M, Ivey KJ. Protection of human gastric epithelial cells in vitro by acetaminophen: role of prostaglandin and sulfhydryls [Abstract]. Gastroenterology 1987; 92: 1599.

39 Tarnawski A, Brzozowski T, Sarfeh IS, Krause WJ, Ulich TR, Gergely H, Hollander D. Prostaglandin protection of human isolated gastric glands against indomethacin and ethanol injury. Evidence for direct cellular action of prostaglandin. J Clin Invest 1988; 81: 1081-9. 